ORAL-POSTER

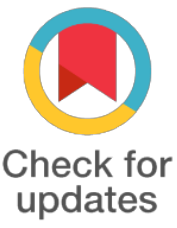

*For correspondence:

satyandas@gmail.com

Competing interests: The authors declare that no competing interests exist.

Received: 2017-06-14 Accepted: 2017-08-11

Published: 2017-09-05

Copyright The Author(s) 2017. This article is published with open access by BioMedPress (BMP)

This article is distributed under the terms of the Creative Commons Attribution License (CC-BY 4.0) which permits any use, distribution, and reproduction in any medium, provided the original author(s) and the source are credited.

\section{Deregulated expression of key components of phosphoinositide 3 kinase pathway in oral squamous cell carcinoma}

\author{
Satya N Das, Manasi Mittal, Manoj K Singh, Suresh C Sharma
}

Departments of Biotechnology, All India institute of Medical Sciences Ansari Nagar, New Delhi, Delhi 110029, India

\section{Abstract}

Oral squamous cell carcinoma (OSCC) is sixth common cancer in males globally. Deregulation of phosphatidylinositol-3-kinase ( $\mathrm{Pl} 3 \mathrm{~K})$ pathway leads to various intracellular responses such as proliferation, survival, and inhibition of apoptosis. We evaluated the expression of key components of $\mathrm{Pl}_{3} \mathrm{~K}$ pathway in OSCC patients. RT-PCR and qRT-PCR was used asses the expression of different AKT isoforms, PTEN, TSC 1 and TSC 2 in tumor and normal tissues. The expression of various components of $\mathrm{Pl}_{3} \mathrm{~K}$ pathway e.g.Ser473PAKT, pan-AKT, PTEN and Ser2448pmTOR and mTOR was evaluated by western blot assay. Effect of selected $\mathrm{Pl}_{3} \mathrm{~K}$ inhibitors on OSCC cells (SCC-4, SCC-9 and SCC-25) was also studied. Approximately 1.4fold higher expression of $A K T_{1}$ and downregulation of $A K T_{2}$ and $A K T_{3}$ mRNA was observed in tumor tissue sections of patients as compared to controls. PTEN, TSC 1 and TSC 2 mRNA was found to be marginally decreases in tumor than the normal area. Significantly strong immunostaining of ser473P-AKT in comparison to AKT1 was documented in all paraffin fixed oral cancer tissues. Additionally, a strong positive correlation between the immunohistochemical expression of AKT-1 and ser473P-AKT in the paraffin sections of oral cancer tissues was observed $(r=0.7504 ; p \leq 0.0001)$. Aberrant expression of key components of $\mathrm{Pl}_{3} \mathrm{~K}$ pathway was also found in OSCC cells that were reversed with the treatment of its inhibitors. Overall, our study suggests that $\mathrm{PI}_{3} \mathrm{~K}$ pathway is deregulated OSCC patients and OSCC cell lines, with $\mathrm{AKT}_{1}$ being the predominantly expressed isoform. $\mathrm{Pl}_{3} \mathrm{~K}$ inhibitors restored such aberrations in OSCC cell lines.

\section{Keywords}

$\mathrm{Pl}_{3} \mathrm{~K}, \mathrm{AKT1}$, mTOR, mRNA, oral cancer.

\section{Funding}

This study was partly funded by Department of Science and Tecnology (DST), Ministry of Science and Technology, Government of India

\section{References}

